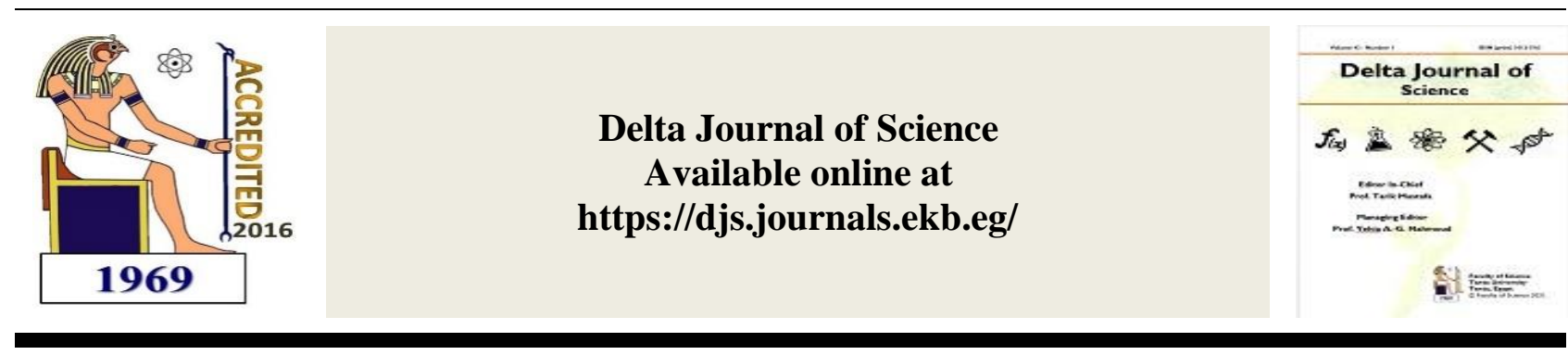

Research Article

BIOCHEMISTRY

\title{
Erythrocyte GST activity in type 2 diabetes with and without nephropathy
}

\section{Sahar S. Bessa ${ }^{1}$, Ehab M.M.Ali ${ }^{2,3}$, Doaa M.El Gamal ${ }^{2}$, Heba I. Makhlouf ${ }^{2}{ }^{*}$ Tarek M. Mohamed $^{2}$}

1. Department of Internal Medicine, Faculty of Medicine, Tanta University, Tanta, Egypt

2. Department of Chemistry, Division of Biochemistry, Faculty of Science, Tanta University, Tanta, Egypt

3. Biochemistry Department, Faculty of Science, King Abdulaziz University, Jeddah, Saudi

* Correspondence: Heba I. Makhlouf

E-mail: hm.heba_makhlouf@yahoo.com

\section{KEY WORDS}

Diabetic

nephropathy;

Oxidative stress;

Glutathione S-

transferase

\section{ABSTRACT}

Diabetic nephropathy (DN) is the main cause of chronic kidney disease, and represents the most common and serious complication of diabetes. The occurrence and progression of DN are closely related to oxidative stress. Excessive reactive oxygen species (ROS) induced by hyperglycemia are involved in direct oxidation and damage of deoxyribonucleic acid (DNA), proteins, and lipids. Glutathione Stransferases have central roles in the cellular detoxification of a diverse group of exogenous and endogenous harmful compounds. The present study aims to clarify the possible role of erythrocyte glutathione Stransferase activity in type 2 diabetic patients with and without nephropathy. This study included 60 diabetic patients (20 diabetics with normoalbuminuria, 20 diabetics with microalbuminuria, 20 diabetics with macroalbuminuria) and 20 healthy volunteers as a control group. Glutathione S- transferase (GST), superoxide dismutase (SOD), glutathione peroxidase (GPx), catalase (CAT) activities, and Reduced glutathione $(\mathrm{GSH})$ level were significantly lower in diabetic patients with and without nephropathy as compared to control. Malondialdehyde (MDA) level was significantly higher in diabetic patients with and without nephropathy as compared to control. GST, SOD, GPx, CAT, GSH and MDA were positively correlated with estimated glomerular filtration rate and negatively correlated with albumin creatinine ratio. It was concluded that erythrocyte GST may be used as a biomarker to differentiate between different groups of nephropathy. 


\section{Introduction}

Diabetes is a group of metabolic diseases characterized by hyperglycemia resulting from defects in insulin secretion, insulin action, or both. The chronic hyperglycemia of diabetes is associated with long-term damage, dysfunction, and failure of different organs, especially the eyes, kidneys, nerves, heart, and blood vessels [1]. Diabetes is a major health problem worldwide. In 2014, according to World Health Organization (WHO), at least 422 million people suffered from type 2 diabetes. Its incidence is increasing rapidly, and it is expected that by 2040, this number will rise to 642 million [2]. In Egypt, type 2 diabetic cases among adults aged 40 - 59 years were 7.8 million in 2015, and it is expected that this number will jump up to 13.1 million by 2035 [3]. Diabetic nephropathy (DN) is the leading cause of endstage renal disease (ESRD). The classical definition of $\mathrm{DN}$ is a progressive rise in urinary albumin excretion (UAE), coupled with increased blood pressure, leading to a decline of glomerular filtration rate (GFR), and eventually end-stage renal failure. About $35-50 \%$ of patients with type 1 or type 2diabetes develop evidence of nephropathy. DN form about $40 \%$ of new cases of ESRD [4]. Glutathione S-transferase (GST) is a family of enzymes that detoxify reactive electrophiles, products of oxidative stress, and suspected carcinogenic compounds through conjugation with reduced glutathione (GSH) [5]. GST is considered a family of phase II detoxification enzymes, acts as an antioxidant through inactivation of endogenous unsaturated aldehydes, quinines, epoxides, and hydroperoxides formed as secondary metabolites during the oxidative stress, thus playing a key role in protecting cell types of various origin, including vascular smooth muscle cells and endothelial cells against oxidant damage. The aim of our study was the evaluation of erythrocyte GST, and another antioxidant enzyme (glutathione peroxidase (Gpx), superoxide dismutase (SOD), and GSH in different cases and severity of diabetic nephropathy. The severity of diabetic nephropathy was determined according to the leakage of albumin from the nephron.

\section{Material and methods Human subjects}

This study was approved by the local Ethical Committee from Tanta University. Approval code: 31314/01/17; all participants gave the written informed consent of their participation. The study included 60 patients with type 2 diabetes and 20 healthy control subjects (group 1). Patients with diabetes were divided into 20 patients with normoalbuminuria (group 11), 20 patients with microalbuminuria (group 11l), and 20 patients with macroalbuminuria (group lV). Patients 
were selected from those admitted to Internal Medicine Department, Tanta University Hospital, their ages ranged from 50 - 62 years. At the time of blood collection, information was recorded for all subjects, including height and weight. All volunteers were asked to answer a questioner about family history of diabetic diseases. Diabetic patients with uncontrolled hypertension, end -stage renal disease, under dialysis, liver disease, cardiac disease, and urinary tract infection were excluded from the study.

\section{Methodology}

A full history was taken with particular emphasis on the duration of diabetes, urinary symptoms, and symptoms of microvascular complications of diabetes, history of any other associated disease, hypertension, cigarette smoking, hypercholesterolemia and therapeutic history. $10 \mathrm{ml}$ of venous blood samples were collected from each subject and divided into: $1 \mathrm{ml}$ of blood was collected in sodium fluoride test tube for determination of fasting blood glucose level (glucose was measured by Spinreact, $2 \mathrm{ml}$ of blood were collected in EDTA sterile vacutainer for determination of glycosylated hemoglobin percentage using Nycocard reader kit (1042184). $2 \mathrm{ml}$ of blood were collected in dry centrifuge tubes then centrifuged for 5 minutes at $3000 \mathrm{rpm}$, the serum was used for determination of creatinine (11502) and urea levels (21516) Kidney function tests were measured by Biosystem kits). $5 \mathrm{ml}$ of whole blood were collected in EDTA vacutainer tube for determination of Glutathione S-transferase (GT 2519) activity, Glutathione peroxidase activity (GP 2524) , superoxide dismutase activity (SD 2521) (using kits from Biodiagnostic), catalase activity according to the method of [6], Reduced Glutathione level was measured by the method of [7] and MDA level by the thiobarbituric acid method [8].

\section{Statistical analysis}

Statistical analysis of the data was performed by Graph Pad Prism version 6.00 for (Graph Pad Software Inc., San Diego, California USA). Descriptive data were given as mean \pm SD. Differences among groups were tested using t-test. One- way ANOVA test was applied to analyse the significance of difference among all groups and control. Chisquared test was applied to test the association between distribution of sex and the studied groups. Statistical significance was defined as the probability of $\mathrm{P}$ value $<0.05$.

\section{Results}

Table (1) shows distribution of age, body mass index and diabetic duration in patient 
groups and control. There is a significant difference between the studied groups, age, and diabetic duration but there is no significant difference in BMI in the studied groups.

Table (2) shows Sex distribution in patient groups and control, there is no significant difference in the studied groups $p>0.05$ and chi square $X 2=5.3$. Table (3) shows kidney function tests in the studied groups. Urea, creatinine and albumin creatinine ratio were significantly increased in diabetics with and without nephropathy as compared to control. While, eGFR was significantly decreased in diabetics with and without nephropathy as compared to control. Table (4) shows antioxidant activities in the studied groups. Erythrocyte GST, SOD, GPx, CAT were significantly decreased in diabetic patients with and without nephropathy as compared to control. Table (5) shows erythrocyte GSH and plasma MDA levels. GSH level was significantly decreased in diabetics with and without nephropathy as compared. MDA level was significantly increased in diabetic patients with and without nephropathy as compared to control.
Table 1: Age, BMI and diabetes duration in the studied groups

\begin{tabular}{|c|c|c|c|c|}
\hline \multirow[b]{2}{*}{ Parameters } & \multirow{2}{*}{$\begin{array}{l}\text { Control } \\
\text { group } \\
(n=20) \\
(I)\end{array}$} & \multicolumn{3}{|c|}{ Type 2 diabetic patients $(n=60)$} \\
\hline & & $\begin{array}{l}\text { DM with } \\
\text { normoalbumin- } \\
\text { uria }(n=20)(\text { (II) }\end{array}$ & $\begin{array}{l}\text { DM with } \\
\text { microalbumi } \\
\mathrm{n} \text {-uria (n= } \\
\text { 20) (III) }\end{array}$ & $\begin{array}{l}\text { DM with } \\
\text { macroalbumi } \\
n \text {-uria ( } n= \\
\text { 20) (IV) }\end{array}$ \\
\hline $\begin{array}{l}\text { Age (years) } \\
\text { Range } \\
\text { Mean } \pm S . D\end{array}$ & $\begin{array}{c}50-60 \\
55.4 \pm 3.0\end{array}$ & $\begin{array}{c}52-60 \\
56.1 \pm 2.6\end{array}$ & $\begin{array}{c}53-61 \\
56.9 \pm 2.5\end{array}$ & $\begin{array}{c}53-62 \\
57.5 \pm 2.9\end{array}$ \\
\hline $\begin{array}{l}F \text { test } \\
P \text { value }\end{array}$ & \multicolumn{4}{|c|}{$\begin{array}{c}2.04 \\
0.1147\end{array}$} \\
\hline $\begin{array}{l}\text { BMI }\left(\mathrm{kg} / \mathrm{m}^{2}\right) \\
\text { Range } \\
\text { Mean } \pm S . D\end{array}$ & $\begin{array}{l}22.0-26.0 \\
24.2 \pm 1.5\end{array}$ & $\begin{array}{c}27.3-30.2 \\
28.7 \pm 1.0\end{array}$ & $\begin{array}{c}28.0-32.0 \\
29.3 \pm 1.3\end{array}$ & $\begin{array}{c}28.5-32.4 \\
30.2 \pm 1.2\end{array}$ \\
\hline $\begin{array}{l}F \text { test } \\
P \text { value }\end{array}$ & \multicolumn{4}{|c|}{$\begin{array}{c}93.15 \\
<0.0001 * \\
\end{array}$} \\
\hline Scheffe test & \multicolumn{4}{|c|}{$\begin{array}{c}0.0001 \text { I vs II, } P= \\
0.0001 \text { I vs III, } P= \\
0.0001 \text { I vs IV, } P= \\
\text { II vs III, } p=0.05 \\
\text { II vs IV, } p=0.01 \\
\text { III vs IV, } p=\text { NS }\end{array}$} \\
\hline $\begin{array}{c}\text { DM duration } \\
\text { (years) } \\
\text { Range } \\
\text { Mean } \pm \text { S.D } \\
\end{array}$ & & $\begin{array}{c}6-11 \\
8.5 \pm 1.8\end{array}$ & $\begin{array}{c}7-13 \\
9.9 \pm 1.7\end{array}$ & $\begin{array}{c}7-15 \\
11.0 \pm 2.4\end{array}$ \\
\hline $\begin{array}{l}F \text { test } \\
P \text { value }\end{array}$ & \multicolumn{3}{|c|}{$0.0012 *$} & \\
\hline Scheffe test & \multicolumn{4}{|c|}{$\begin{array}{c}\text { II vs III, P = NS } \\
\text { II vs IV, P = 0.001 } \\
\text { III vs IV, } p=\text { NS }\end{array}$} \\
\hline
\end{tabular}

*Significant $(P<0.05)$; NS= Non significant.

Table 2: Sex distribution in patient groups and control

\begin{tabular}{|c|c|c|c|c|c|c|c|c|}
\hline \multirow{3}{*}{ Sex } & & & \multicolumn{6}{|c|}{ Type 2 diabetic patients $(n=60)$} \\
\hline & \multicolumn{2}{|c|}{$\begin{array}{l}\text { Control } \\
\text { group } \\
(n=20) \\
\text { (I) }\end{array}$} & \multicolumn{2}{|c|}{$\begin{array}{c}\text { DM with } \\
\text { normoalbumi } \\
\text { n-uria ( } n=20) \\
\text { (II) }\end{array}$} & \multicolumn{2}{|c|}{$\begin{array}{c}\text { DM with } \\
\text { microalbumi } \\
\text { n-uria (n= } \\
\text { 20) (III) }\end{array}$} & \multicolumn{2}{|c|}{$\begin{array}{c}\text { DM with } \\
\text { macroalbu } \\
\text { min-uria } \\
(n=20)(I V\end{array}$} \\
\hline & $\mathbf{n}$ & $\%$ & $\mathbf{n}$ & $\%$ & $\mathbf{n}$ & $\%$ & $\mathbf{n}$ & $\%$ \\
\hline Male & 11 & 55 & 13 & 65 & 14 & 70 & 8 & 40 \\
\hline Female & 9 & 45 & 7 & 35 & 6 & 30 & 12 & 60 \\
\hline $\begin{array}{c}X^{2} \\
P \text { value }\end{array}$ & \multicolumn{8}{|c|}{$\begin{array}{c}5.333 \\
0.1490 \text { NS }\end{array}$} \\
\hline
\end{tabular}

NS= Non significant; $X^{2}$, chi-squared distribution 
Table 3: Kidney function tests in the studied groups

*Significant $\quad(\mathrm{P}<0.05) ; \quad$ eGFR, estimated

\begin{tabular}{|c|c|c|c|c|}
\hline \multirow[b]{2}{*}{ Parameters } & \multirow[b]{2}{*}{$\begin{array}{l}\text { Contro } \\
\text { I group } \\
(\mathrm{n}=20) \\
(\mathrm{I})\end{array}$} & \multicolumn{3}{|c|}{ Diabetic patients $(n=60)$} \\
\hline & & $\begin{array}{c}\text { DM with } \\
\text { normoalbumi } \\
\text { n-uria ( } n=20) \\
\text { (II) }\end{array}$ & $\begin{array}{c}\text { DM with } \\
\text { microalbumi } \\
\text { n-uria (n= 20) } \\
\text { (III) }\end{array}$ & $\begin{array}{c}\text { DM with } \\
\text { macroalbu } \\
\text { min-uria ( } n= \\
\text { 20) (IV) } \\
\end{array}$ \\
\hline $\begin{array}{c}\text { Creatinine } \\
\text { (mg/dl) } \\
\text { Range } \\
\text { Mean } \pm \text { S.D }\end{array}$ & $\begin{array}{c}0.7-1.0 \\
0.82 \pm \\
0.1\end{array}$ & $\begin{array}{c}0.7-1.6 \\
1.02 \pm 0.2\end{array}$ & $\begin{array}{c}1.3-2.5 \\
1.53 \pm 0.4\end{array}$ & $\begin{array}{c}1.4-3.0 \\
1.94 \pm 0.3\end{array}$ \\
\hline $\begin{array}{l}\text { F test } \\
P \text { value }\end{array}$ & \multicolumn{4}{|c|}{$\begin{array}{c}66.1 \\
0.0001^{*}\end{array}$} \\
\hline Scheffe test & \multicolumn{4}{|c|}{$\begin{array}{r}0.00010 .0001, I \text { vs IV, } P=\text { NS, I vs III, } P=I \text { vs III, } P= \\
0.0001 \text { III vs IV, } P=0.00010 .0001 \text {, II vs IV, } P=\mid I \text { vs III, } P=\end{array}$} \\
\hline $\begin{array}{l}\text { Urea }(\mathrm{mg} / \mathrm{dl}) \\
\quad \text { Range } \\
\text { Mean } \pm \text { S.D }\end{array}$ & $\begin{array}{c}24-33 \\
28.4 \pm 2.5\end{array}$ & $\begin{array}{c}30-50 \\
38.4 \pm 6.9\end{array}$ & $\begin{array}{c}43-75 \\
57.2 \pm 10.8\end{array}$ & $\begin{array}{c}59-100 \\
74.3 \pm 12.9\end{array}$ \\
\hline $\begin{array}{l}\text { F test } \\
P \text { value }\end{array}$ & \multicolumn{4}{|c|}{$\begin{array}{c}97.5 \\
0.0001^{*}\end{array}$} \\
\hline Scheffe test & \multicolumn{4}{|c|}{$\begin{array}{r}0.00010 .0001, \text { I vs IV, } P=0.01 \text {, I vs III, } P=I \text { vs II, } P= \\
0.00010 .0001 \mathrm{III} \text { vs IV, } P=0.0001 \text {, II vs IV, } P=I I \text { vs III, } P=\end{array}$} \\
\hline $\begin{array}{c}\text { eGFR }(\mathrm{mL} / \mathrm{min} \\
\text { per } 1.73 \mathrm{m2}) \\
\text { Range } \\
\text { Mean } \pm \text { S.D }\end{array}$ & $\begin{array}{c}53-129 \\
101.4 \pm 19.9\end{array}$ & $\begin{array}{c}50-87 \\
71.8 \pm 10.5\end{array}$ & $\begin{array}{c}36-60 \\
52.7 \pm 6.8\end{array}$ & $\begin{array}{c}32-37 \\
33.6 \pm 1.9\end{array}$ \\
\hline $\begin{array}{l}\text { F test } \\
P \text { value }\end{array}$ & \multicolumn{4}{|c|}{$\begin{array}{c}119.7 \\
0.0001^{*}\end{array}$} \\
\hline Scheffe test & \multicolumn{4}{|c|}{$\begin{array}{c}0.00010 .0001, \text { I vs IV, } P=0.0001, I \text { vs III, } P=I \text { vs II, } P= \\
0.00010 .0001, I I \text { vs IV, } P=\| \text { vs III, } P= \\
0.0001 \text { III vs IV, } P=\end{array}$} \\
\hline $\begin{array}{c}\text { ACR } \\
\text { (mg/gCr) } \\
\text { Range } \\
\text { Mean } \pm S . D\end{array}$ & $\begin{array}{c}6-14 \\
7.9 \pm 1.9\end{array}$ & $\begin{array}{c}9.5-28 \\
17.1 \pm 6.3\end{array}$ & $\begin{array}{c}40-190 \\
87.2 \pm 35.6\end{array}$ & $\begin{array}{c}430-763 \\
581.3 \pm 108.1\end{array}$ \\
\hline $\begin{array}{l}\text { F test } \\
P \text { value }\end{array}$ & \multicolumn{4}{|c|}{$\begin{array}{c}462.3 \\
0.0001^{*}\end{array}$} \\
\hline Scheffe test & \multicolumn{4}{|c|}{$\begin{array}{c}0.00010 .001, \text { I vs IV, } P=N S \text {, I vs III, } P=\text { I vs II, } P= \\
0.0001 \| I \text { vs IV, } P=0.00010 .001 \text {, II vs IV, } P=\| \text { vs III, } P=\end{array}$} \\
\hline
\end{tabular}

glomerular filtration rate; ACR, albumin creatinine ratio
Table 4: Erythrocyte glutathione S-transferase, superoxide dismutase, and glutathione peroxidase and catalase activities in the studied groups

\begin{tabular}{|c|c|c|c|c|}
\hline \multirow[b]{2}{*}{ Parameters } & \multirow{2}{*}{$\begin{array}{c}\text { Control } \\
\text { group } \\
(n=20) \\
\text { (I) }\end{array}$} & \multicolumn{3}{|c|}{ Diabetic patients $(n=60)$} \\
\hline & & $\begin{array}{l}\text { DM with } \\
\text { normoalbu } \\
\text { min-uria (n= } \\
\text { 20) (II) }\end{array}$ & $\begin{array}{l}\text { DM with } \\
\text { microalbumi } \\
\text { n-uria (n= } \\
\text { 20) (III) }\end{array}$ & $\begin{array}{c}\text { DM with } \\
\text { macroalbumi } \\
\text { uria }(n=20) \\
\text { (IV) }\end{array}$ \\
\hline $\begin{array}{l}\text { GST(U/g Hb) } \\
\text { Range } \\
\text { Mean } \pm S . D\end{array}$ & $\begin{array}{c}52-64 \\
58.8 \pm 3.7\end{array}$ & $\begin{array}{r}39-47.5 \\
43.2 \pm 2.7\end{array}$ & $\begin{array}{c}35-40 \\
37.7 \pm 1.6\end{array}$ & $\begin{array}{l}22.2-25.2 \\
23.7 \pm 0.97\end{array}$ \\
\hline $\begin{array}{l}F \text { test } \\
P \text { value }\end{array}$ & \multicolumn{4}{|c|}{$\begin{array}{c}670.3 \\
0.0001^{*}\end{array}$} \\
\hline Scheffe test & \multicolumn{4}{|c|}{$\begin{array}{l}0.0001^{*} 0.0001^{*}, I \text { vs IV, } P=0.0001^{*}, I \text { vs III, } P=I \text { vs II, } P= \\
0.0001^{*} 0.0001^{*} \text { III vs IV, } P=0.0001^{*}, I \text { vs IV, } P=I \text { vs III, } P\end{array}$} \\
\hline $\begin{array}{l}\text { SOD }(U / g ~ H b) \\
\text { Range } \\
\text { Mean } \pm S . D\end{array}$ & $\begin{array}{l}17.2-25.5 \\
20.2 \pm 2.8\end{array}$ & $\begin{array}{c}13-15.5 \\
14.1 \pm 0.82\end{array}$ & $\begin{array}{l}11.5-13.2 \\
12.3 \pm 0.55\end{array}$ & $\begin{array}{c}11-12.8 \\
11.9 \pm 0.54\end{array}$ \\
\hline $\begin{array}{l}F \text { test } \\
P \text { value }\end{array}$ & \multicolumn{4}{|c|}{$\begin{array}{c}124.8 \\
0.0001^{*}\end{array}$} \\
\hline Scheffe test & \multicolumn{4}{|c|}{$\begin{array}{l}0.0001^{*}, \text { I vs IV, } P=0.0001^{*} 0.0001^{*}, I \text { vs III, } P=I \text { vs II, } P= \\
\text { NS } 0.0001^{*} \text { III vs IV, } P=0.01^{*} \text {, II vs IV, } P=I I \text { vs III, } P=\end{array}$} \\
\hline $\begin{array}{l}\mathrm{GPx}(\mathrm{mU} / \mathrm{mL}) \\
\text { Range } \\
\text { Mean } \pm \text { S.D }\end{array}$ & $\begin{array}{c}442-452 \\
447.9 \pm 3.1\end{array}$ & $\begin{array}{c}413-419 \\
416.5 \pm 2.0\end{array}$ & $\begin{array}{c}397-405 \\
401.2 \pm 2.4\end{array}$ & $\begin{array}{c}378-387 \\
382.6 \pm 2.7\end{array}$ \\
\hline $\begin{array}{l}F \text { test } \\
P \text { value }\end{array}$ & \multicolumn{4}{|c|}{$\begin{array}{c}2188 \\
0.0001^{*}\end{array}$} \\
\hline Scheffe test & \multicolumn{4}{|c|}{$\begin{array}{c}0.0001^{*} 0.0001^{*}, \text { I vs IV, } P=0.0001^{*}, \text { I vs III, } P=I \text { vs II, } P= \\
0.0001^{*} \text { III vs IV, } P=\text { II vs III, } P=0.0001^{*}, \text { II vs IV, } P= \\
0.0001^{*}\end{array}$} \\
\hline $\begin{array}{c}\mathrm{CAT}(\mu \mathrm{mol} \\
/ \mathrm{min} / \mathrm{g} \mathrm{Hb}) \\
\text { Range } \\
\text { Mean } \pm \text { S.D }\end{array}$ & $\begin{array}{c}65-82 \\
73.4 \pm 5.2\end{array}$ & $\begin{array}{c}47-66 \\
56.5 \pm 5.9\end{array}$ & $\begin{array}{c}36-58 \\
45.6 \pm 6.2\end{array}$ & $\begin{array}{c}25-39 \\
30.8 \pm 4.4\end{array}$ \\
\hline $\begin{array}{l}F \text { test } \\
P \text { value }\end{array}$ & \multicolumn{4}{|c|}{$\begin{array}{c}214.7 \\
0.0001 *\end{array}$} \\
\hline Scheffe test & \multicolumn{4}{|c|}{$\begin{array}{l}0.0001^{*} 0.0001^{*}, \text { I vs IV, } P=0.0001^{*}, \text { I vs III, } P=I \text { vs II, } P= \\
0.0001^{*} 0.0001^{*} \text { III vs IV, } P=0.0001^{*} \text {, II vs IV, } P=I \text { vs III, } P=\end{array}$} \\
\hline
\end{tabular}

*Significant $(\mathrm{P}<0.05)$; GST, glustathione $\mathrm{S}$ transferase; SOD, superoxide dismutase; GPx, glutathione peroxidase; CAT, catalase 
Table 5: Erythrocyte reduced glutathione and plasma malondialdehyde levels in the studied groups

\begin{tabular}{|c|c|c|c|c|}
\hline \multirow[b]{2}{*}{ Parameters } & \multirow{2}{*}{$\begin{array}{l}\text { Control } \\
\text { group } \\
(n=20) \\
\text { (I) }\end{array}$} & \multicolumn{3}{|c|}{ Diabetic patients $(n=60)$} \\
\hline & & $\begin{array}{l}\text { DM with } \\
\text { normoalbum } \\
\text { in-uria ( } n= \\
\text { 20) (II) }\end{array}$ & $\begin{array}{c}\text { DM with } \\
\text { microalbumi } \\
\text { n-uria ( } n=20) \\
\text { (III) }\end{array}$ & $\begin{array}{c}\text { DM with } \\
\text { macroalbu } \\
\text { min-uria ( } n= \\
\text { 20) (IV) }\end{array}$ \\
\hline $\begin{array}{c}\text { GSH } \\
(\mu \mathrm{mol} / \mathrm{g} \\
\mathrm{Hb}) \\
\text { Range } \\
\text { Mean } \pm S . D \\
\end{array}$ & $\begin{array}{l}52-69 \\
58 \pm 5.3\end{array}$ & $\begin{array}{c}46-53 \\
49.6 \pm 2.1\end{array}$ & $\begin{array}{c}42-50 \\
45.9 \pm 2.6\end{array}$ & $\begin{array}{c}37-47 \\
41.8 \pm 3.0\end{array}$ \\
\hline $\begin{array}{l}\text { F test } \\
P \text { value }\end{array}$ & \multicolumn{4}{|c|}{$\begin{array}{c}77.6 \\
0.0001^{*}\end{array}$} \\
\hline Scheffe test & \multicolumn{4}{|c|}{$\begin{array}{l}0.0001^{*} 0.0001^{*}, I \text { vs IV } P=0.0001^{*} \text { I vs III, } P=I \text { vs II, } P= \\
0.0001^{*} \text { III vs IV, } P=0.01^{*} 0.01^{*}, \text { II vs IV, } P=\text { II vs III, } P=\end{array}$} \\
\hline $\begin{array}{c}\text { MDA } \\
\text { (nmol/ } \mathrm{mL} \text { ) } \\
\text { Range } \\
\text { Mean } \pm \text { S.D } \\
\end{array}$ & $\begin{array}{c}4-4.7 \\
4.4 \pm 0.2\end{array}$ & $\begin{array}{l}6.1-6.9 \\
6.6 \pm 0.2\end{array}$ & $\begin{array}{c}7-7.7 \\
7.3 \pm 0.2\end{array}$ & $\begin{array}{l}7.3-7.9 \\
7.6 \pm 0.1\end{array}$ \\
\hline $\begin{array}{l}F \text { test } \\
P \text { value }\end{array}$ & \multicolumn{4}{|c|}{$\begin{array}{l}1007 \\
0.0001^{*}\end{array}$} \\
\hline Scheffe test & \multicolumn{4}{|c|}{$\begin{array}{l}0.0001^{*} 0.0001 \text { vs III, } P 0.0001^{*}=, \text { I vs IV, } P=\text { I vs II, } P= \\
\text { NS } 0.0001^{*} \text { III vs IV, } P=\text { II vs III, } P=0.0001^{*} \text {, II vs IV, } P=\end{array}$} \\
\hline
\end{tabular}

*Significant $\quad(\mathrm{P}<0.05) ; \quad \mathrm{GSH}, \quad$ reduced glutathione;

MDA, malondialdehyde; NS: Non significant

\section{Discussion}

Diabetic nephropathy (DN) is the main cause of chronic kidney disease, and represents the most common and serious complication of diabetes. The exact pathogenesis of DN is complex and not elucidated. Several factors and mechanisms contribute to the development and outcome of DN. An early diagnosis and intervention may slow down disease progression [5]. The occurrence and progression of DN are closely related to oxidative stress. Excessive ROS, which is induced by hyperglycemia, is involved in oxidative stress causing direct oxidation and damage of deoxyribonucleic acid (DNA), proteins and lipids [9]. Hyperglycemia is associated with the production of ROS in diabetic patients .The production of ROS is considered to be one of the major causes of diabetic complications, including nephropathy[10].

Glutathione $\mathrm{S}$ transferases

(GSTs) represent a superfamily of enzymes involved in cell protection and detoxification. The main function of these enzymes is the conjugation of GSH to toxic hydrophobic compounds provided by an electrophilic center. This reaction facilitates toxins inactivation and renal elimination of a large number of toxins [11]. GSTs constitute one of the major components of phase II drug-metabolizing enzyme and antioxidant systems .Therefore, there is an increasing interest in the role that polymorphisims in phase I and phase II detoxification enzymes may play role in the etiology and progression of diseases. [12,13]. In the current study, the activity of glutathione S- transferase was significantly decreased in diabetic groups with and without nephropathy as compared to control (Table 4). These findings are supported by $[14,15,16]$ who reported that GST activity was decreased in diabetic patients as compared to control. Conversely, [17] reported that GST activity was significantly increased in diabetic patients as compared to controls, then reached its 
highest values in diabetics with nephropathy. In the present study, the activity of superoxide dismutase (SOD) was significantly decreased in diabetic groups with and without nephropathy as compared to control (Table 4). Similar results were obtained by $[18,19]$ who reported that SOD activity was significantly decreased in diabetics with and without nephropathy as compared to control due to higher oxidative stress produced by high glucose levels. In the current study, the activity of glutathione peroxidase (GPx) was significantly decreased in diabetic groups with and without nephropathy as compared to control. Similar results were obtained by $[18,20]$ and [21] who reported that GPx activity was significantly decreased in diabetics with and without nephropathy as compared to control. In our study, catalase activity was significantly decreased in diabetic groups with and without nephropathy as compared to control. These findings are supported by [22,23]. A further reduction in catalase activity in patients with diabetic nephropathy may be due to a higher magnitude of oxidative stress in these subjects. On the contrary, [24] reported that catalase activity was significantly increased in diabetics with and without nephropathy as compared to control. Moreover, [25] reported an increase in CAT activity, which overcomes the damaging effect of the erythrocyte membrane from oxidative attack. In our study, reduced glutathione(GSH) level was significantly decreased in diabetics with and without nephropathy as compared to control. This coincides with [18] reported a significant decrease in GSH level in diabetics as compared to controls. Glutathione is thiolcontaining tripeptides which in its reduced form $(\mathrm{GSH})$ is present in living cells at high concentrations. When it reacts with ROS, it gets oxidized to glutathione radical which is regenerated to its reduced form through glutathione reductase activity. A significant decrease in GSH concentration in diabetic groups may be due to conversion of reduced form to oxidized form (GSSH) by excessive production of reactive oxygen species[18]. In the current study, malondialdehyde (MDA) level was significantly increased in diabetic groups with and without nephropathy as compared to control. Similar to our results, [20] presented an increased MDA level in diabetics with and without nephropathy because of reduced activity of most of the antioxidant enzymes.

\section{Conclusion}

Oxidative stress (OS) and antioxidant status may be linked with glycemic control and probably contribute to the development of diabetic complications. It also suggested that an increase in GST could be an adaptive and protective response in patients with diabetes from the progression of DN. MDA and GSH 
levels preceding the development of diabetes complications might be considered good indicators for evaluating OS in complications of T2DM such as DN. Thus, the monitoring of the studied oxidative stress parameters as early predictors of DN in patients of T2DM should be considered. Antioxidants could be useful in the management of $\mathrm{DN}$ to prevent progressive deterioration and target organ damage however; further studies involving long-term clinical trials may help to assess the efficacy of these therapeutic agents.

\section{References}

[1] American Diabetes Association (2017): Classification and diagnosis of diabetes. Diabetes care; 40(Supplement 1): S11-S24.

[2] Singh N. (2017): Study on prevalence of hypertension, diabetes mellitus and their few risk factors among rural women in Ghaziabad. Int J Community Med Public Heal; 4: 1488-1493.

[3] Sandu, M.-M., Protasiewicz, D. C., Firănescu, A. G., Lăcătuşu, E. C., Bîcu, M. L. and Moţa, M. (2016):Data regarding the prevalence and incidence of diabetes mellitus and prediabetes. Romanian Journal of Diabetes Nutrition and Metabolic Diseases; 23(1): 95-103.

[4] Yuan, C. M., Nee, R., Ceckowski, K. A., Knight, K. R. and Abbott, K. C. (2017): Diabetic nephropathy as the cause of endstage kidney disease reported on the medical evidence form CMS2728 at a single center. Clinical Kidney Journal; 10(2): 257-262.

[5] Bessa, S. S., Ali, E. M. and Hamdy, S. M. (2009): The role of glutathione Stransferase M1 and T1 gene polymorphisms and oxidative stress-related parameters in Egyptian patients with essential hypertension. European Journal of Internal Medicine;20(6): 625-630.

[6] Sinha, A. K. (1972): Colorimetric assay of catalase. Analytical biochemistry; 47(2): 389-394.

[7] Beutler, E. (1963):Improved method for the determination of blood glutathione. J. lab. clin. Med; 61:882-888

[8] Esterbauer, H. and Cheeseman, K. H. (1990): Determination of aldehydic lipid peroxidation products: malonaldehyde and 4-hydroxynonenal Methods in enzymology (Vol. 186, pp. 407-421): Elsevier.

[9] Giacco, F. and Brownlee, M. (2010): Oxidative stress and diabetic complications. Circulation research, 107(9), 1058-1070.

[10] Yang, Y., Kao, M.-T., Chang, C.-C., Chung, S.-Y., Chen, C.-M., Tsai, J. J. and Chang, J.-G. (2004): Glutathione Stransferase $\mathrm{T} 1$ deletion is a risk factor for developing end-stage renal disease in diabetic patients. International journal of molecular medicine; 14(5): 855-859.

[11] Robertson, R. P., Harmon, J., Tran, P. O., Tanaka, Y. and Takahashi, H. (2003): Glucose toxicity in $\beta$-cells: type 2 diabetes, good radicals gone bad, and the glutathione connection. Diabetes; 52(3): 581-587.

[12] Pinheiro, D. S., Rocha Filho, C. R., Mundim, C. A., de Marco Júnior, P., Ulhoa, C. J., Reis, A. A. and Ghedini, P. C. (2013):Evaluation of glutathione Stransferase GSTM1 and GSTT1 deletion polymorphisms on type-2 diabetes mellitus risk. PLoS One; 8(10): e76262.

[13] Wang, G., Zhang, L. and Li, Q. (2006): Genetic polymorphisms of GSTT1, GSTM1, and NQO1 genes and diabetes mellitus risk in Chinese population. Biochemical and biophysical research communications; 341(2): 310-313. 
[14] Datta, S. K., Kumar, V., Ahmed, R. S., Tripathi, A. K., Kalra, O. P. and Banerjee, B. D. (2010): Effect of GSTM1 and GSTT1 double deletions in the development of oxidative stress in diabetic nephropathy patients.

[15] Verma, S., Sagar, N., Vats, P., Shukla, K., Abbas, M. and Banerjee, M. (2013): Antioxidant enzyme levels as markers for type 2 diabetes mellitus. Int $\mathrm{J}$ Bioassay; 2(4): 685-690.

[16] Rao, D. K., Shaik, N. A., Imran, A., Murthy, D. K., Ganti, E., Chinta, C., Rao, H., Shaik, N. S. and Al-Aama, J. Y. (2014): Variations in the GST activity are associated with single and combinations of GST genotypes in both male and female diabetic patients. Molecular biology reports; 41(2): 841-848.

[17] Noce, A., Fabrini, R., Dessì, M., Bocedi, A., Santini, S., Rovella, V., Pastore, A., Tesauro, M., Bernardini, S. and Di Daniele, N. (2014): Erythrocyte glutathione transferase activity: a possible early biomarker for blood toxicity in uremic diabetic patients. Acta diabetologica; 51(2): 219-224.

[18] Mistry, K. N., Dabhi, B. K. and Joshi, B. B. (2020): Evaluation of oxidative stress biomarkers and inflammation in pathogenesis of diabetes and diabetic nephropathy. Indian Journal of Biochemistry and Biophysics (IJBB), 57(1), 45-50.

[19] Kaushik, R., Dige, M., Dass, G., Ramachandran, N. and Rout, P. (2018): Superoxide dismutase activity in response to heat stress in Jamunapari goats.

[20] Gupta, S., Gambhir, J. K., Kalra, O., Gautam, A., Shukla, K., Mehndiratta, M., Agarwal, S. and Shukla, R.
(2013):Association of biomarkers of inflammation and oxidative stress with the risk of chronic kidney disease in Type 2 diabetes mellitus in North Indian population. Journal of Diabetes and its Complications; 27(6): 548-552.

[21] Blum, J. and Fridovich, I. (1985): Inactivation of glutathione peroxidase by superoxide radical. Archives of Biochemistry and Biophysics; 240(2): 500508.

[22] Pan, H.-z., Zhang, L., Guo, M.-y., Sui, H., Li, H., Wu, W.-h., Qu, N.-q., Liang, M.-h., Chang, D. (2010): The oxidative stress status in diabetes mellitus and diabetic nephropathy. Acta diabetologica; 47(1): 7176.

[23] Chou, S.-T., Tseng, S.-T. (2017): Oxidative stress markers in type 2 diabetes patients with diabetic nephropathy. Clinical and experimental nephrology; 21(2): 283292.

[24] Kumar, P. A. Rajagopal, G. (2003): Lipid peroxidation in erythrocytes of patients with type 2 diabetes mellitus. Indian journal of clinical biochemistry; 18(1): 71-74.

[25] Selvam, R. and Anuradha, C. (1988): Lipid peroxidation and antiperoxidative enzyme changes in erythrocytes in diabetes mellitus. Indian journal of biochemistry \& biophysics; 25(3): 268. 
تقييم نشاط الجلوتاثيون إس ترنسفيراز فى اغشية كرات الدم الحمراء في مرضي البول السكري من النوع الثاني المصحوب وغير المصحوب بالإعتلال الكلوي

\author{
سحر سعد الدين بسه ( ') ، إيهاب مصطفي محمد علي (r،r) ، دعاء محمود الجمل (r) هبه \\ إبرا (هيم مخلوف (r) ، طارق مصطفى محمد على (r)

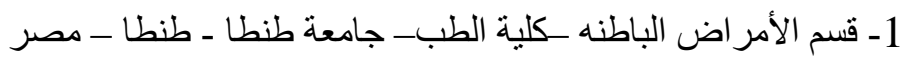

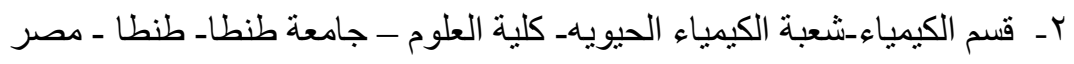

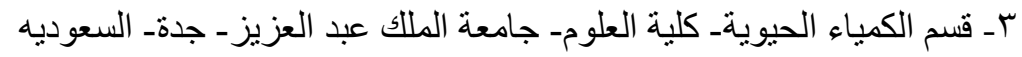

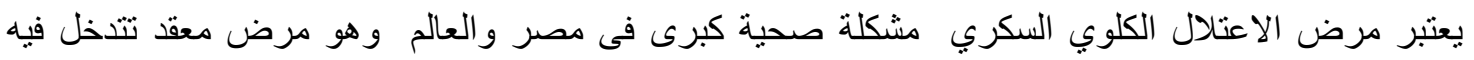

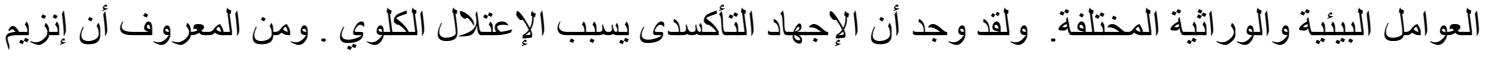

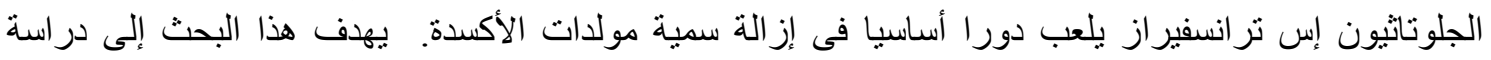

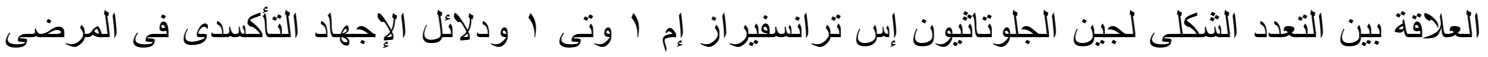

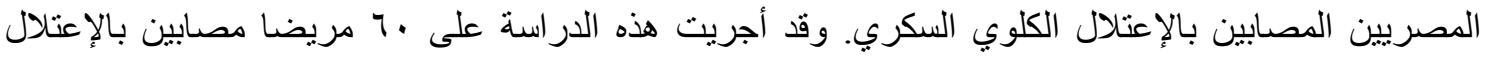

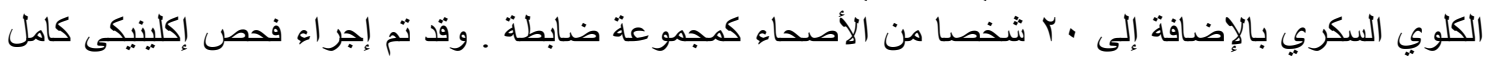

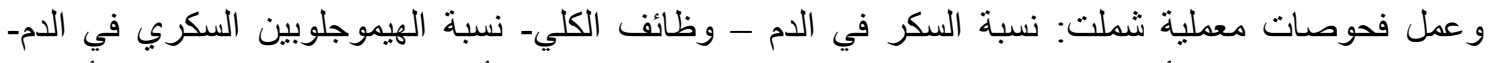

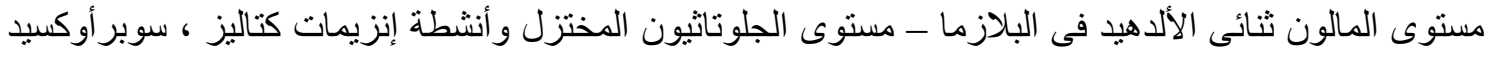

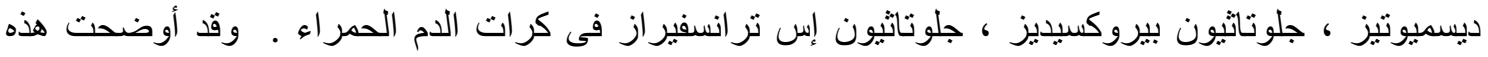

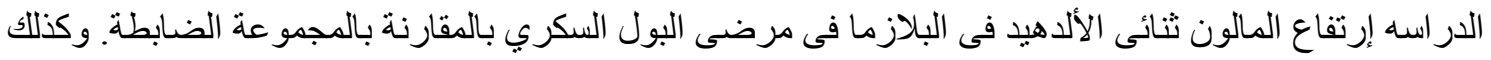

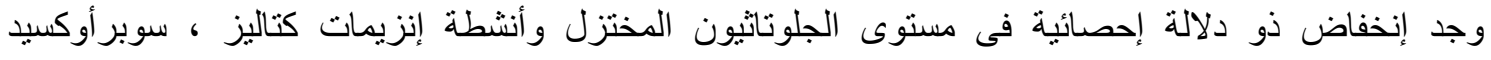

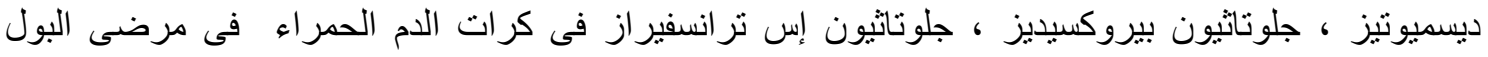

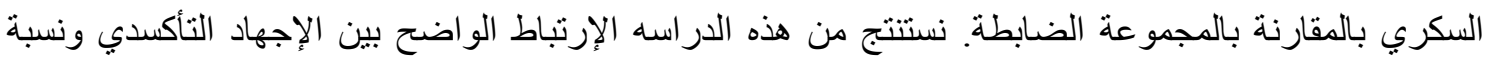

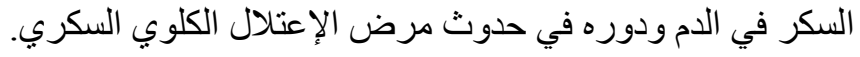

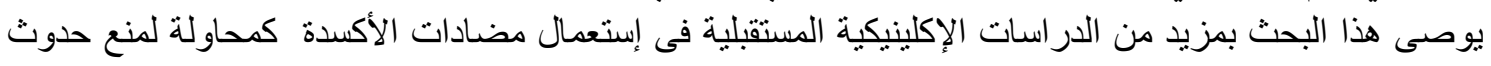
و علاج مرض الإعنلال الكلوي السكري ومضاعفاته على العز العضاء الجسم المختلفة. 